http://dx.doi.org/10.15762/ZH.2015.15

\title{
PROFESOR STANISŁAW ALEXANDROWICZ (1931-2015) IN MEMORIAM
}

Dnia 9 IV 2015 r. zmarł prof. Stanisław Alexandrowicz, jeden z najwybitniejszych historyków kartografii dawnej Rzeczypospolitej, znakomity znawca dziejów Wielkiego Księstwa Litewskiego, a także badacz niektórych aspektów najnowszej historii Polski.

Stanisław Alexandrowicz urodził się 5 IV 1931 r. w Wilnie, w rodzinie urzędnika państwowego Bohdana oraz nauczycielki Marii z Kukowiczów. Wczesne dzieciństwo spędził w Wilnie i Łucku. W tym ostatnim mieście zastała go wojna, która okazała się tragiczna dla losów rodziny. Już 24 IX 1939 r. aresztowano jego ojca, który następnie - z rozkazu sowieckiego trybunału wojskowego - został rozstrzelany 28 XII 1939 r. Reszta rodziny, w tym dwie siostry, w kwietniu 1940 r. została wywieziona do Kazachstanu, do miejscowości Majkain-Zołoto (obwód Pawłodar). Dopiero w latach dziewięćdziesiątych dane było prof. S. Alexandrowiczowi wrócić do tego miejsca, w którym odkrył istniejące wciąż jeszcze groby swoich sióstr zmarłych podczas zesłania. Do Polski wrócił w 1946 r. i osiadł w Toruniu, gdzie matka uzyskała etat lektorki na Uniwersytecie Mikołaja Kopernika w Toruniu. Tutaj w 1953 r. ukończył studia historyczne I stopnia, uczestnicząc w seminariach profesorów Karola Górskiego i Bronisława Włodarskiego. Następnie studiował historię na Uniwersytecie im. Adama Mickiewicza w Poznaniu. Uczęszczał tam na seminaria profesorów Henryka Łowmiańskiego, Gerarda Labudy i Kazimierza Tymienieckiego. Największy wpływ na dalsze losy S. Alexandrowicza wywarł jednak ten pierwszy, u którego napisał pracę magisterską traktującą o handlu Polski z Rusią Kijowską (do roku 1240), ogłoszoną później drukiem ${ }^{1}$. Z ukończeniem studiów magisterskich, w styczniu 1955 r., podjął pracę w Wojewódzkim Archiwum Państwowym w Poznaniu, by pół roku później rozpocząć studia aspiranckie (doktoranckie), przygotowując rozprawę „Funkcje gospodarcze miasteczek Litwy i Białorusi do połowy XVII w." Została ona napisana pod kierunkiem H. Łowmiańskiego i obroniona w grudniu 1960 r. Następnie S. Alexandrowicz pracował na stanowisku adiunkta w Instytucie Historii UAM. Tam też habilitował się w maju 1972 r. (rozprawa habilitacyjna: „Rozwój kartografii Wielkiego Księstwa Litewskiego do połowy XVII wieku"). Zaowocowało to awansem na stanowisko docenta w Zakładzie Historii Narodów ZSRR w Instytucie Historii UAM, gdzie pracował

${ }^{1}$ Stanisław Alexandrowicz, Stosunki handlowe polsko-ruskie do roku 1240, Zeszyty Naukowe Uniwersytetu im. Adama Mickiewicza. Historia, z. 3, Poznań 1958, s. 21-67. 
do 1977 r., od roku akademickiego 1973/1974, prowadząc też własne seminarium magisterskie. Trzeba zauważyć, że także w okresie późniejszym Profesor zawsze podkreślał swoje bliskie związki z poznańską „lituanistyką” i całym Uniwersytetem im. Adama Mickiewicza. Stąd tak bardzo ucieszył się z odnowienia jego doktoratu na tej uczelni, które nastąpiło w $2010 \mathrm{r}$.

Od listopada 1977 r. S. Alexandrowicz był zatrudniony w filii Uniwersytetu Warszawskiego w Białymstoku, wywierając znaczący wpływ na rozwój badań w tworzącym się tam Instytucie Historycznym. Ważne były także podejmowane tam przez niego działania o charakterze organizacyjnym. Pełnił on bowiem funkcję Prodziekana Wydziału Humanistycznego (1978-1984), a także Kierownika Zakładu Historii Starożytnej i Średniowiecznej w Instytucie Historii (1978-1988). Nie sposób nie podkreślić jego ówczesnych zasług na polu kształcenia. W Białymstoku wykształcił ponad 50 magistrów. Ze środowiska białostockiego pochodziło też pięciu doktorów, którzy napisali prace doktorskie pod jego kierunkiem (w sumie było ich dwunastu). Wiele $\mathrm{z}$ powstałych wówczas prac magisterskich oraz doktorskich dotyczyło historii Podlasia. Należy podkreślić, że Profesor zdziałał wiele dla zintensyfikowania badań nad dziejami tej krainy zarówno jako naukowiec, jak i wykładowca uniwersytecki. Nie dziwi więc, że w 1984 r. stanął na czele nowo powstałej wówczas Pracowni Badań nad Historią i Kulturą Regionu w strukturze Instytutu Historii, filii Uniwersytetu Warszawskiego zlokalizowanej w Białymstoku. Przez wiele lat był też członkiem, a przez pewien czas również prezesem, Białostockiego Towarzystwa Naukowego. Szczególnie leżało mu na sercu ocalenie pamięci o podlaskich „małych ojczyznach”, często niewielkich miejscowościach, w których żyło jeszcze wielu ludzi pamiętających ważne historyczne wydarzenia z XX w. Stąd inicjowane przez niego zbieranie przez studentów i doktorantów świadectw w postaci nagrań i wywiadów z żywymi świadkami historii, a w rezultacie powstawanie prac magisterskich poświęconych szeregu podlaskich miejscowości.

W październiku 1987 r. - nie zrywając kontaktów z filią UW w Białymstoku (gdzie też ponownie pracował na etacie w latach 1995-2001) - dzięki namowom prof. Andrzeja Tomczaka S. Alexandrowicz rozpoczął pracę na Uniwersytecie Mikołaja Kopernika w Toruniu na stanowisku kierownika Zakładu Historii Narodów ZSRR, przemianowanego w 1989 r. na Zakład Historii Europy Wschodniej w strukturze Instytutu Historii i Archiwistyki. Odegrał olbrzymią rolę we wskrzeszeniu zlikwidowanych tam w latach stalinowskich badań nad historią Europy Wschodniej w epoce nowożytnej (ich praktycznym przejawem była likwidacja Katedry Historii Europy Wschodniej w 1951 r.), będąc kontynuatorem działalności takich historyków, jak: Ryszard Mienicki i Leonid Żytkowicz, którzy po drugiej wojnie światowej przybyli do Torunia z Wilna. Inicjowane kierunki badań dotyczyły szczególnie historii Wielkiego Księstwa Litewskiego oraz ziem ruskich Korony. Już jako pracownik UMK S. Alexandrowicz uzyskał profesurę nadzwyczajną w 1989 r., a następnie zwyczajną w 1994 r. W okresie swojej pracy na UMK wykształcił ponad 60 magistrów, a także dalszych kilku doktorów. Po formalnym 
przejściu na emeryturę w 2001 r. pracował jeszcze przez kilka lat jako wykładowca w Instytucie Stosunków Międzynarodowych UMK (na Wydziale Politologii i Studiów Międzynarodowych), a następnie także w Wyższej Szkole Kultury Społecznej i Medialnej w Toruniu.

Twórczość naukowa prof. S. Alexandrowicza jest wyjątkowo bogata. Mam tu na myśli zarówno różne obszary jego historycznych poszukiwań, jak i ich chronologię. Pod względem chronologicznym obejmuje ona okres od średniowiecza aż po wiek XX. Najwięcej uwagi Zmarły poświęcił jednak historii nowożytnej. Największe zasługi S. Alexandrowicz położył niewątpliwie w dwóch dziedzinach badań historycznych.

Pierwszą z nich, przez wiele lat znajdującą się na najważniejszym miejscu wśród jego badawczych zainteresowań, była historia kartografii dawnej Rzeczypospolitej w XVI-XVIII w. Spod jego ręki wyszło w sumie blisko 100 publikacji naukowych $\mathrm{z}$ tej dziedziny ${ }^{2}$. Najwybitniejszym, syntetycznym dziełem Profesora stała się monografia Rozwój kartografii Wielkiego Księstwa Litewskiego od XV do połowy XVIII wieku, która doczekała się trzech wydań (1972, 1989, 2012 - ta edycja pod tytułem Kartografia Wielkiego Księstwa Litewskiego od XV do połowy XVIII wieku), $\mathrm{z}$ tego każde następne wydanie było poprawione i wydatnie uzupełnione. Ostatnia edycja została okraszona przepięknymi reprodukcjami map (jakość reprodukcji w dwóch wcześniej wydanych książkach pozostawiała wiele do życzenia). Profesor nie doczekał się niestety wydania wyboru swoich najważniejszych artykułów dotyczących historii kartografii, który niebawem ukaże się w formie odrębnej publikacji książkowej.

Wśród najważniejszych osiągnięć badawczych Profesora w tej dziedzinie należy wymienić odkrycie dla nauki i opisanie najdokładniejszego planu Moskwy sprzed wielkiego pożaru z 1611 r., który około 1606-1608 r. wykonał mieszczanin nieświeski Szymon Jędraszewicz Śmiotański vel Śmietański (a sztychował w 1611 r. Tomasz Makowski) na polecenie wojewody wileńskiego Mikołaja Krzysztofa Radziwiłła „Sierotki”. Z postacią tego ostatniego wiążą się też badania S. Alexandrowicza nad „mapą radziwiłłowską" i odkrywcze ustalenia dotyczące pierwszego zaginionego jej wydania. Wyniki tych naukowych eksploracji weszły do kanonu światowej nauki, co ułatwił kilkakrotny udział Profesora w międzynarodowych kongresach historyków kartografii, odbywających się w Jadwisinie pod Warszawą (1977), Pizie, Florencji i Rzymie (1981), Paryżu (1987) oraz w Uppsali i Sztokholmie (1991). Jeśli chodzi o liczne odkrycia kartograficzne Profesora, należy jeszcze wskazać odnalezienie przez niego jednych z najstarszych map majątkowych Rzeczypospolitej - pochodzących z terenów Podlasia i pogranicza litewsko-pruskiego z drugiej i trzeciej ćwierci XVI w. Na szczególne podkreślenie zasługują też studia S. Alexandrowicza nad staropolską kartografią wojskową. W tej dziedzinie również dokonał ważnych odkryć i badań, które zaowocowały m.in. publikacją i opisaniem

\footnotetext{
${ }^{2}$ Większość z nich zestawiona jest w publikacji: Jerzy Ostrowski, Siedemdziesięciolecie urodzin Profesora Stanisława Alexandrowicza, Polski Przegląd Kartograficzny, t. 33: 2001, nr 2, s. $162-167$.
} 
planów oblężeń Połocka z 1579 r. i zamku Uły z 1568 r. czy planów obronnych obozów wojsk polskich pod Zbarażem i Zborowem. Ich odpowiednia interpretacja zmieniła właściwie dotychczasowy obraz walk prowadzonych przez oddziały Rzeczypospolitej przeciw Kozakom i Tatarom w 1649 r. Nie sposób wymienić tu choćby tylko ważniejsze publikacje Profesora dotyczące historii kartografii, wspomnijmy więc jedynie, że opisują one działalność oraz dzieła takich kartografów, jak: Bernard Wapowski, Józef Naronowicz-Naroński, Tomasz Makowski, Jan Nieprzecki, Karol de Perthées, Stanisław Pachołowiecki, Stanisław Porębski, Georg von Schwengeln i innych. Wszystkie te publikacje niosły wiele nowych szczegółowych ustaleń, a całościowo traktowane ukazały kartografię dawnej Rzeczypospolitej jako dziedzinę bardzo dobrze rozwiniętą, również w porównaniu z państwami Europy Zachodniej. Na polu historii kartografii staropolskiej S. Alexandrowicz pozostawał po śmierci Karola Buczka bodaj najwybitniejszym znawcą i ekspertem, czego dowodem były także syntetyczne ujęcia dotyczące kartografii całej dawnej Rzeczypospolitej, w których pisaniu brał udział , czy też omówienia badań na tym polu4. Uczestniczył też w przygotowaniu pomnikowego wydawnictwa, mianowicie Katalogu dawnych map Rzeczypospolitej Polskiej w kolekcji Emeryka Hutten-Czapskiego. Zasługi odniesione w badaniach nad dziejami kartografii sprawiły, że Profesor był wieloletnim (od momentu powstania w 1975 r.) członkiem Zespołu Historii Kartografii, działającego przy Instytucie Historii Nauki PAN, a w latach 1995-2005 przewodniczył temu zespołowi.

Kariera naukowa S. Alexandrowicza zaczęła się jednak od jego badań nad ośrodkami miejskimi Wielkiego Księstwa Litewskiego i Podlasia (zarówno części koronnej, jak i litewskiej) w końcu lat pięćdziesiątych i we wczesnych latach sześćdziesiątych XX w. Były to badania pionierskie, a ich wyniki do dziś pozostają aktualne. Powoływali się na nie (i nadal powołują) w wielu szczegółowych i syntetycznych rozprawach historycy: białoruscy, polscy, litewscy i przedstawiciele innych nacji. Obszerna praca doktorska poświęcona tym zagadnieniom ostatecznie ukazała się w postaci kilku odrębnych artykułów: Geneza i rozwój sieci miasteczek Białorusi i Litwy do połowy XVII w.; Zaludnienie miasteczek Litwy i Białorusi w XVI i pierwszej połowie XVII w.; Miasteczka Białorusi i Litwy jako ośrodki handlu w XVI i w pierwszej połowie XVII wieku. Zasługą autora było przede wszystkim zwrócenie uwagi na rolę, jaką odgrywały w gospodarce Wielkiego Księstwa Litewskiego małe miasta i miasteczka, ukazanie ich struktury oraz funkcjonowania w nich handlu i rzemiosła. W ten sposób powstał - z uwzględnieniem badań nad większymi ośrodkami miejskimi - obraz urbanizacji Wielkiego Księstwa Litew-

\footnotetext{
${ }^{3}$ Stanisław Alexandrowicz, Radosław Skrycki, Jarosław Łuczyński, Historia kartografi, Warszawa 2014; Stanisław Alexandrowicz, Karol BuczeK, Polska kartografia wojskowa do połowy XVII wieku, [in:] Dzieje polskiej kartografii wojskowej i myśli strategicznej. Materiały z konferencji, red. Bogusław Krassowski, Jadwiga MADEJ, Warszawa 1982, s. 7-32.

${ }^{4}$ Stanisław AleXANDrowicz, Rozwój badań nad historia staropolskiej kartografii w latach 1918-1984, [in:] Z dziejów kartografii, t. 6: Dorobek polskiej historii kartografii, red. Julian JANCZAK, Wiesława Wernerowa, Warszawa 1993, s. 27-49.
} 
skiego do połowy XVII w. Należy zwrócić uwagę, że Profesor jako pierwszy podkreślił wpływ środowisk miejskich na procesy polonizacyjne występujące na tych obszarach, przede wszystkim wśród miejscowej ludności pochodzenia ruskiego (w artykule Rola miast $i$ miasteczek $w$ przemianach kulturalnych $i$ jezzkowych na ziemiach Białorusi w XVI-XVIII w.). Wcześniej uwypuklano przede wszystkim przemożną rolę szlachty $\mathrm{w}$ tych procesach. S. Alexandrowicz poświęcił też kilka ze swoich publikacji ukazaniu osadnictwa oraz roli ludności żydowskiej w gospodarce mniejszych miast Wielkiego Księstwa Litewskiego. Najważniejsze publikacje Profesora dotyczące badań nad ośrodkami miejskimi w późnym średniowieczu i okresie nowożytnym kilka lat temu zostały wydane w osobnym tomie pt. Studia $z$ dziejów miasteczek Wielkiego Księstwa Litewskiego (Toruń 2011). Książka ta zawiera też unikalny zestaw źródeł (przywileje na prawo magdeburskie, inwentarz, opis zabudowy oraz ordynację) do historii jednego z magnackich miast Wielkiego Księstwa Litewskiego w XVII w., mianowicie Lubcza.

Przeżycia związane z zesłaniem w okresie dzieciństwa i wczesnej młodości stanowiły istotny powód, dla którego S. Alexandrowicz zajął się także w swej pracy naukowej badaniami dotyczącymi najnowszej historii. Za szczególnie ważny, również $\mathrm{w}$ kontekście wzajemnych relacji polsko-rosyjskich $\mathrm{w}$ ostatnim ćwierćwieczu, należy uznać udział Profesora w przygotowaniu (razem ze Zbigniewem Karpusem i Waldemarem Rezmerem) zbioru dokumentów poświęconego jeńcom polskim w niewoli bolszewickiej pt. Zwycięzcy $z a$ drutami. Jeńcy polscy $w$ niewoli (1919-1922). Dokumenty i materiały (Toruń 1995). Publikacja ta w jakimś stopniu stanowiła odpowiedź na kłamliwe tezy części polityków, publicystów i historyków rosyjskich oskarżających polskie władze o celową eksterminację jeńców Armii Czerwonej przebywających w niewoli w Polsce po wojnie polsko-bolszewickiej.

$\mathrm{Z}$ tegoż okresu dziejów wymienić trzeba też artykuły S. Alexandrowicza poświęcone początkom lotnictwa polskiego i rosyjskiego, a konkretnie pionierowi lotów arktycznych Janowi Nagórskiemu ${ }^{5}$, Polakom w lotnictwie rosyjskim do $1914 \mathrm{r}^{6}{ }^{6}$, a także w lotnictwie bolszewickim w latach 1917-19207. Ukazały one, przemilczany $\mathrm{w}$ literaturze radzieckiej, a niedostatecznie naświetlony $\mathrm{w}$ historiografii współczesnej Rosji, wkład Polaków w rozwój lotnictwa rosyjskiego.

W ostatnich latach najbardziej leżały Profesorowi na sercu badania nawiązujące bezpośrednio do czasu zesłania. Podkreślmy, że nie tylko jako naukowiec, lecz także jako aktywny członek Związku Sybiraków dążył do wyświetlenia pełnej prawdy o tamtych wydarzeniach. Na tyle, na ile pozwalało mu zdrowie, badał historię zesłańców do Kazachstanu. W związku z tym przymierzał się do napi-

${ }^{5}$ Idem, Pierwszy lotnik arktyczny - Jan Nagórski (1888-1976), Kwartalnik Historii Nauki i Techniki, R. 23: 1978, nr 2, s. 365-395.

${ }^{6}$ Idem, Polacy w rozwoju awiacji rosyjskiej (do 1914 r.), [in:] Polsko-rosyjskie zwiazki społeczno-kulturalne na przełomie XIX i XX wieku, red. Marian Leczyk, Warszawa 1980, s. 350-383.

${ }^{7}$ Idem, Polacy w lotnictwie radzieckim podczas rewolucji i wojny domowej, [in:] Polska i jej sasiedzi w czasach najnowszych. Studia i materialy ofiarowane profesorowi Karolowi Grünbergowi w 70-lecie urodzin, red. Mieczysław Wojciechowski, Toruń 1995, s. 29-43. 
sania analitycznego studium o losach około 11,5 tysiąca zesłańców polskich do obwodu pawłodarskiego. Jak twierdził: „szczególnie ważne wydaje się uzyskanie odpowiedzi na pytanie, - jakie były szanse przeżycia, w zależności od lokalnych warunków". W kontekście badań nad polskimi zesłańcami z okresu drugiej wojny światowej podkreślał potrzebę przeprowadzenia szerokiej kwerendy w lokalnych posowieckich archiwach (m.in. w Kazachstanie). Prowadził tam poszukiwania archiwalne dwukrotnie. Zgodnie $\mathrm{z}$ jego słowami celem tych badań miała być weryfikacja błędów, m.in. dotyczących liczby wywiezionych w latach 1940-1941 z terenów wschodnich Rzeczypospolitej jej obywateli, a zawartych w ustaleniach przyjętych $\mathrm{w}$ dotychczasowej historiografii, opartych przede wszystkim na niepełnych danych (głównie na dokumentach wojsk konwojowych NKWD), a pochodzących jedynie z centralnych archiwów rosyjskich w Moskwie. Na podstawie swoich badań w archiwach Kazachstanu Profesor gotów był podnieść liczbę wszystkich wywiezionych w czterech falach wywózek (w lutym, kwietniu i czerwcu/lipcu $1940 \mathrm{r}$. oraz w czerwcu 1941 r.) z przyjmowanej oficjalnie około 330-360 tysięcy osób do około 440 tysięcy, a nie wykluczał, że liczba ta mogła być jeszcze wyższå ${ }^{8}$.

Jako nauczyciel akademicki, jak na historyka kartografii przystało, S. Alexandrowicz podkreślał zawsze konieczność dobrego wykorzystania źródeł ikonograficznych, często w innym świetle ukazujących problem badawczy, jak pokazały to niektóre jego publikacje (np. te dotyczące planów obozów pod Zbarażem i Zborowem). Jako prowadzący seminarium magisterskie zawsze trzymał się zasady, że pisana przez studentów praca winna wnosić do nauki coś nowego. Podkreślał też konieczność bezpośredniego sięgania do źródeł, również rękopiśmiennych (jeśli tylko jest to możliwe), a także krytycznego podejścia do istniejącej historiografii. Z tej zapewne przyczyny wiele $\mathrm{z}$ prac powstałych na seminarium Profesora, szczególnie w okresie białostockim i toruńskim, otrzymało nagrody i wyróżnienia (najwięcej w konkursach im. prof. Stanisława Herbsta organizowanych przez Polskie Towarzystwo Historyczne), a część z nich została też opublikowana. Takie podejście do pracy seminaryjnej wynikało, jak S. Alexandrowicz sam zauważał, z jego wcześniejszych doświadczeń nabytych szczególnie podczas studiów poznańskich. Nie może więc dziwić fakt, że także w jego publikacjach znać znakomity warsztat naukowy. Zawsze były one świetnie udokumentowane, a stawiane w nich tezy głęboko przemyślane.

Stanisław Alexandrowicz był członkiem wielu międzynarodowych i krajowych towarzystw naukowych, a także rad czasopism (m.in. „Polskiego Przeglądu Kartograficznego”, „Przeglądu Wschodniego”, „Lituano-Slavica Posnaniensia. Studia Historica”, „Studiów Podlaskich”, „Białoruskich Zeszytów Historycznych”, „Czasów Nowożytnych") i różnego rodzaju instytucji naukowych. Nie sposób je tu wszystkie wymienić. Wspomnijmy tu tylko jego uczestnictwo w Komitetach: Slawistyki i Nauk Historycznych PAN (w różnych komisjach), a także w Radzie Naukowej Biblioteki Narodowej w Warszawie.

${ }^{8}$ Zob. idem, Sześćdziesiąt lat temu 10 lutego 1940 r., Niedziela, R. 43, nr 6 (268) z 6 II 2000 r. 
Trzeba też przypomnieć tu o wielkiej pasji Profesora - szybownictwie. Zawsze z prawdziwym przejęciem opowiadał o swoich lotach nad Tatrami. Uprawiał ten sport przeszło 30 lat. W związku z tym od 1958 r. był członkiem Aeroklubu Poznańskiego, a w latach 1971-1975 jego Prezesem. Jako szybownik otrzymał złotą odznakę szybowcową z jednym diamentem. Był z niej bardzo dumny. Podobnie jak z Krzyża Oficerskiego Orderu Odrodzenia Polski, który otrzymał w 2009 r. z rąk Prezydenta Lecha Kaczyńskiego.

Profesor S. Alexandrowicz był życzliwym, serdecznym i pełnym swoistego humoru człowiekiem, jak z rękawa „sypiącym” setkami anegdot i historyjek z życia wziętych. Miał też dar opowiadania o rzeczach trudnych, w tym o okresie zesłania, bez zbędnego patosu. Zawsze podkreślał, jak wiele on i jego bliscy zawdzięczali wielu spotkanym podczas zesłania Kazachom. Stąd leżał mu bardzo na sercu współczesny los tego państwa. Podobnie rzecz się miała z Białorusią, z której terenów - konkretnie z ziemi brasławskiej - wywodziła się jego rodzina. Starał się też pomagać, w różny zresztą sposób, historykom białoruskim. Stąd darzony był niezwykłym szacunkiem wśród tej grupy naukowców z Białorusi.

Wielu osobom, w tym także mnie, trudno sobie wyobrazić, że nie zobaczymy już jakże charakterystycznego widoku Profesora, obładowanego stosem książek schowanych w przepastnej torbie, kursującego regularnie pociągami między Toruniem, Białymstokiem, Warszawą i Poznaniem, a czasami także innymi miastami. W swoją ostatnią drogę Profesor wyruszył 14 IV 2015 r. z Torunia do Poznania, gdzie jego doczesne szczątki spoczęły na cmentarzu Jeżyckim.

Tomasz Kempa (Toruń) 